\title{
Gravity effect of glacial ablation in the Eastern Alps - observation and modeling
}

\author{
P. Arneitz ${ }^{1}$, B. Meurers ${ }^{1}$, D. Ruess ${ }^{2}$, C. Ullrich ${ }^{2}$, J. Abermann ${ }^{3,}$, and M. Kuhn ${ }^{3,4}$ \\ ${ }^{1}$ University of Vienna, Department of Meteorology and Geophysics, Vienna, Austria \\ ${ }^{2}$ Federal Office of Metrology and Surveying, Vienna, Austria \\ ${ }^{3}$ Austrian Academy of Sciences, Commission for Geophysical Research, Vienna, Austria \\ ${ }^{4}$ University of Innsbruck, Institute of Meteorology and Geophysics, Innsbruck, Austria \\ * now at: Centro de Estudios Avanzado en Zonas Áridas (CEAZA), La Serena, Chile
}

Correspondence to: B. Meurers (bruno.meurers@univie.ac.at)

Received: 24 October 2012 - Published in The Cryosphere Discuss.: 3 December 2012

Revised: 13 February 2013 - Accepted: 6 March 2013 - Published: 21 March 2013

\begin{abstract}
Absolute gravity measurements have been regularly performed in the Austrian Eastern Alps since 1985. A gravity increase of $300 \mathrm{~nm} \mathrm{~s}^{-2}$ has been observed so far. The gravity trend is explained by ablation effects within surrounding glaciers. Ice thickness changes derived from 3 successive glacier inventories of 1969, 1997 and 2006 are used for quantitative 3-D modeling based on rectangular prisms with basis areas of $\leq 8 \mathrm{~m} \times 8 \mathrm{~m}$. Local topographic changes due to man-made mass displacements close to the measuring site are modeled by a polyhedron approach. Two-thirds $(2 / 3)$ of the observed gravity increase can be explained by the ablation model response and man-made effects. A positive trend of about $100 \mathrm{~nm} \mathrm{~s}^{-2}$ remains. The origin of the residual trend remains open. Correcting for geodynamical processes like Alpine uplift or postglacial deformation is expected to cause a slight increase of this trend. The observed gravity signal shows seasonal gravity variations as well, which are probably due to snow cover effects but cannot be quantified due to the lack of appropriate snow cover information.
\end{abstract}

\section{Introduction}

Global warming and associated climate change during the recent decades is one of the main reasons for glacier retreat in the Alps. Mémin et al. (2009) quantified the gravity effects of present-day ice thinning in the vicinity of the Mont Blanc region (France) and the Svalbard (Norway) glaciers both due to the Newtonian and the deformation signal. They also showed the strong topographic influence on the expected results. We present, to our knowledge for the first time, observed gravity variations and relate them quantitatively to ice mass balance information derived from glacier inventories in the Eastern Alps. Regular absolute gravity observations have been performed by the Federal Office of Metrology and Surveying (BEV) in Austria since 1985 in order to establish and control the Austrian gravity network (Ruess and Gold, 1996). One of the absolute gravity stations has been established in the central part of the Eastern Alps which is known to exhibit moderate recent uplift of roughly $1 \mathrm{~mm} \mathrm{yr}^{-1}$ (Höggerl, 2001; Ruess and Höggerl, 2002). This estimate results from repeated leveling observations performed in Austria between 1948 and 1962 and between 1966 and 1990. All results of these campaigns refer to a reference station located in the Bohemian massif which is assumed to be stable. Recently, slight rising of the Alps in Austria has been confirmed by vertical velocity estimates based on GPS coordinate time series starting in 2000 (Haslinger et al., 2007). Supporting geodynamical and tectonic investigations of the area by absolute gravity observations is the main purpose of this inner-Alpine station.

It has been established in the small village Obergurgl (Tyrol, Austria), surrounded by glacier-capped mountains of the so-called Ötztal Alps and Stubai Alps (Fig. 1). The station is located at $1935 \mathrm{~m}$ a.s.l. at $11^{\circ} 01^{\prime} 30^{\prime \prime} \mathrm{E}, 46^{\circ} 52^{\prime} 01^{\prime \prime} \mathrm{N}$. All surrounding glacier areas extend at higher altitudes. To reduce floor recoil effects, a concrete pier has been connected directly to the underlying rocks in the basement of the Alpine Research Site Obergurgl (operated by the University 


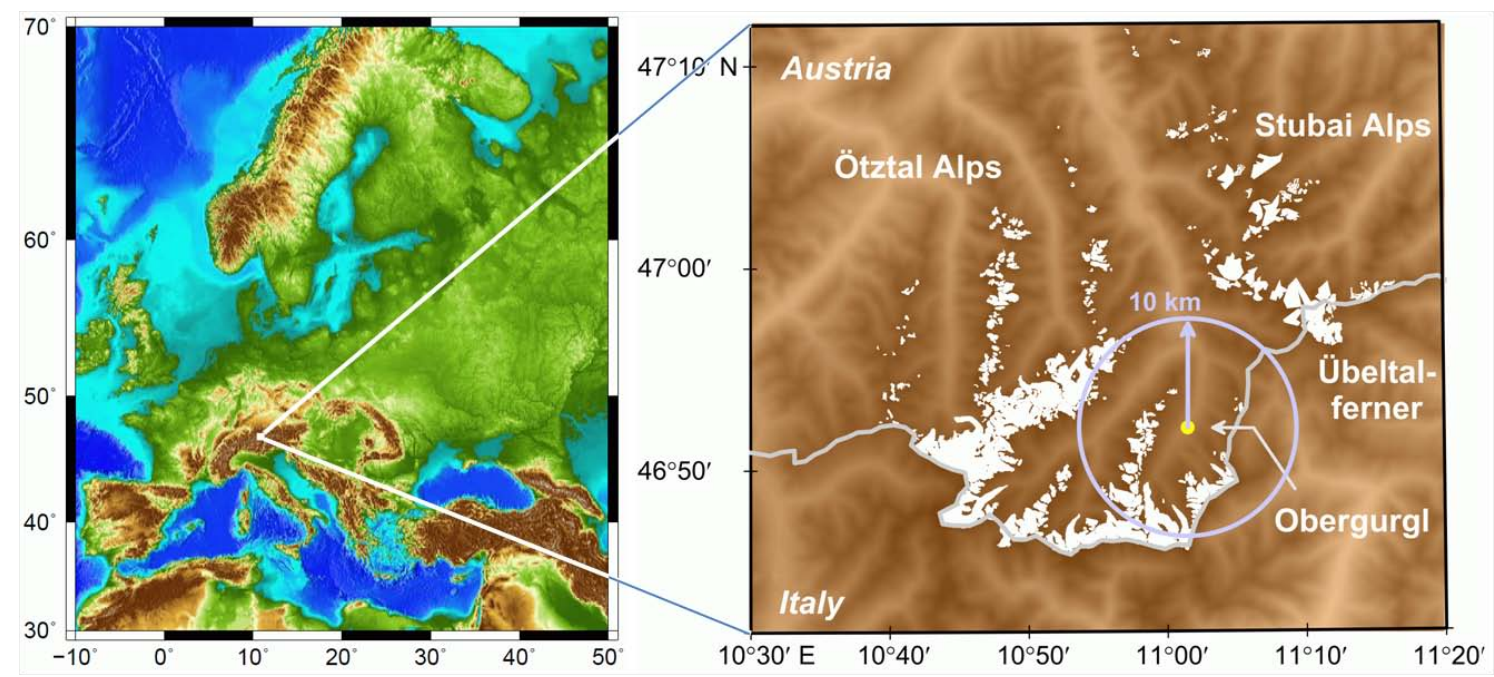

Fig. 1. Location of the absolute gravity station Obergurgl and surrounding glaciers considered in this paper. The map of the left panel is based on the ETOPO2v2 Global Gridded 2 min Database, National Geophysical Data Center, National Oceanic and Atmospheric Administration, US Dept. of Commerce, http://www.ngdc.noaa.gov/mgg/global/etopo2.html, and was drawn using the software by Wessel and Smith (1991). Right panel: Glacier areas in 1997 (white). The grey line shows the border between Austria and Italy. The yellow dot marks the gravity station at Obergurgl.

of Innsbruck). Due to the lack of traffic and industrial activity the noise level is low. BEV tried to perform measurements on a semi-annual basis to get information on seasonal gravity variations due to the snow cover as well (Ruess, 1993). In total 32 absolute gravity campaigns have been performed between 1987 and 2009 in spring and autumn of each year. During the spring campaigns the snow cover in the surroundings is expected to be maximal, while during the autumn observations the area is widely free from seasonal snow.

Over the whole period a positive gravity trend of a few hundred $\mathrm{nm} \mathrm{s}^{-2}$ has been observed (Fig. 2) (Ullrich and Ruess, 2006). This is quite surprising, because the contrary is expected due to the rise of mean elevations caused by the uplift of the Alps. For the area around Obergurgl the vertical velocity has been estimated by approximately $1.5 \mathrm{~mm} / \mathrm{yr}$ (Ruess and Höggerl, 2002). Haslinger et al. (2007) report vertical velocities between 1 and $2 \mathrm{~mm} \mathrm{yr}^{-1}$ at two GPS stations closest to Obergurgl. The geodynamical interpretation of the gravity trend implies appropriate modeling of other environmental effects on gravity. Abermann et al. (2009) analyzed digital elevation models (DEMs) for different years (1969, 1997 and 2006) and quantified the ice mass losses in the region of the Ötztal Alps. Seiser (2010) performed a similar investigation of the Stubai Alps' glaciers. Here we calculate the associated gravity response of these nearby ice mass losses to explain the observed gravity trend.

\section{Absolute gravity time series}

For all absolute gravity measurements the transportable freefall absolute gravimeter JILAg-6 has been used. The mea- surement uncertainty of JILAg-6 is under best control as it participated regularly at the International Comparison of $\mathrm{Ab}$ solute Gravimeters (ICAGs) campaigns at the Bureau International des Poids et Mesures (BIPM) between 1981 and 2009 (Ruess and Ullrich, 2011). During the campaign in 2005 a comparison reference value (CRV) was defined as a set of gravity values valid at a height of $0.9 \mathrm{~m}$ above the benchmark and derived from common adjustment of all absolute and relative gravity measurement results (Jiang et al., 2011). Ruess and Ullrich (2011) discussed the performance of the JILAg-6 that has participated six times at the ICAGs since 1989 and evaluated the deviations of JILAg-6 from CRV with a standard deviation of $\pm 60 \mathrm{~nm} \mathrm{~s}^{-2}$. This number matches the measurement uncertainty of approximately $80 \mathrm{~nm} \mathrm{~s}^{-2}$ of the JILAg- 6 and can therefore be used for error estimations.

The reference height of JILAg-6 is defined as $0.84 \mathrm{~m}$ above the floor for most observations in Obergurgl, corresponding to the position at about $1 / 3$ of the free-fall distance (Zumberge, 1981). The effective height depends on the instrumental setup and the used start and stop fringe. Its determination is still under debate (e.g. Niebauer, 1989; Timmen, 2003). However, in this study the observed absolute gravity values are compared relatively; therefore the exact height offset is not relevant as long as it is kept constant over the years. All observed gravity data have been reprocessed using the software package ETERNA (Wenzel, 1994) to subtract the tides and the pole motion effect. To include the ocean loading effect, main tidal parameters based on a 1-by 1-degree grid of Schwiderski's (1980) ocean tide model are interpolated (Timmen and Wenzel, 1994). A constant admittance 
factor of $3 \mathrm{~nm} \mathrm{~s}^{-2} \mathrm{hPa}^{-1}$ has been selected for atmospheric pressure corrections. This concept is widely used in absolute gravimetry, but it does not consider the frequency dependency of the admittance function (e.g. Warburton and Goodkind, 1977). Actually the atmospheric pressure admittance varies between 2 and $4 \mathrm{~nm} \mathrm{~s}^{-2} \mathrm{hPa}^{-1}$ in the amplitude spectrum (e.g. Neumeyer and Pflug, 1997). For most observations in Obergurgl, the differences between observed air pressure and that of the standard atmosphere covered a range of less than $10 \mathrm{hPa}$. The air pressure correction error can therefore be estimated as less than $10 \mathrm{~nm} \mathrm{~s}^{-2}$.

A specific campaign consisted of 2-5 independent experiments, after which the instrumental setup was controlled and re-adjustments were made when required. Its final gravity was calculated as the weighted mean of all experiments. The absolute gravity time series at Obergurgl is displayed in Fig. 2. Blue and red dots represent the results obtained by the campaigns in spring and autumn, respectively. A clear positive trend is visible that is statistically significant on the $0.1 \%$ level. The linear fit to all observations independent of the season yields an average trend of $14.0 \pm 1.5 \mathrm{~nm} \mathrm{~s}^{-2} \mathrm{yr}^{-1}$, i.e. an overall gravity increase of $308 \mathrm{~nm} \mathrm{~s}^{-2}$ between 1987 and 2009. The trends showing up in the spring and autumn observations are statistically significant as well $(0.1 \%)$ and vary between $13.0 \mathrm{~nm} \mathrm{~s}^{-2} \mathrm{yr}^{-1}$ (spring) and $14.2 \mathrm{~nm} \mathrm{~s}^{-2} \mathrm{yr}^{-1}$ (autumn). The systematic effect of snow cover is reflected by the average offset of about $64 \mathrm{~nm} \mathrm{~s}^{-2}$ between the results from autumn and spring observations. However, the details cannot be quantified due to the lack of snow cover data.

\section{Glacier inventories}

Most of the glaciers in the surroundings of the observation site are well investigated by episodic glacier inventories (Patzelt, 1980; Lambrecht and Kuhn, 2007; Kuhn et al., 2008; Abermann et al., 2009, 2010; Seiser, 2010) and partly by periodic mass balance measurements (Kuhn et al., 1999; Fischer and Markl, 2009; WGMS, 2011). Both in the Ötztal and Stubai Alps, the glacier inventories provided DEMs of the upper glacier surface valid for the years 1969 and 1997 based on analogue and digital airborne photogrammetry (Fig. 1). The DEMs for 2006 were derived by high-resolution airborne lidar. All inventory data were acquired between August and October, making all data sets closely comparable. The Stubai Alps extend over the Austrian-Italian border; however, DEMs are only available for the Austrian territory. On the Italian side, there is one major glacier called Übeltalferner (Fig. 1). Here, ice mass variation can only be derived from mass balance observations since 2001 (R. Dinale, personal communication, 2011).

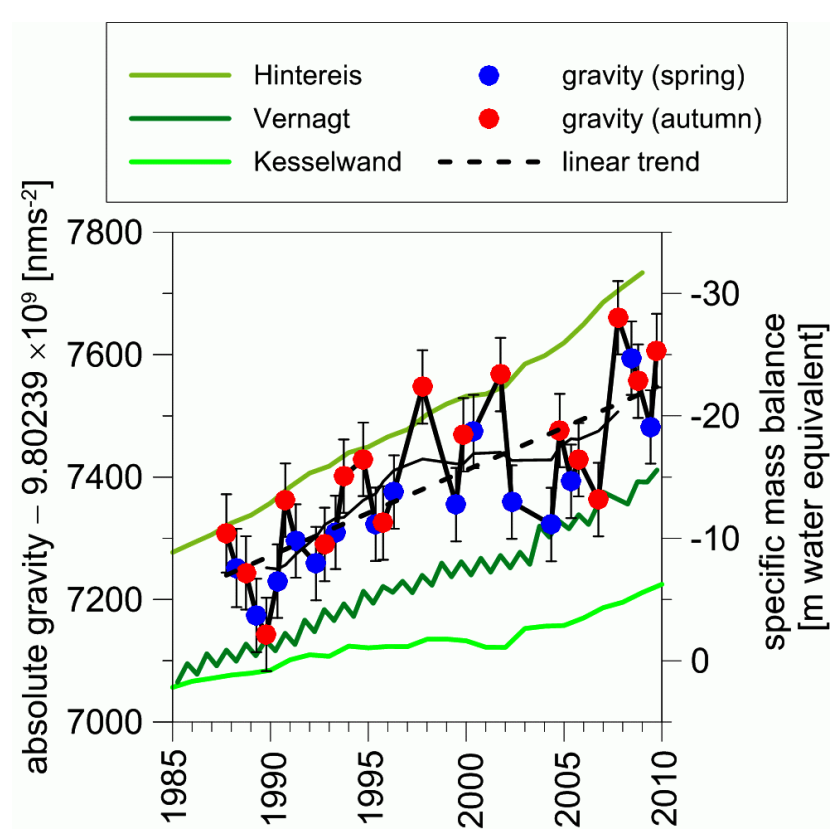

Fig. 2. Absolute gravity time series at Obergurgl (weighted means of each campaign) between 1987 and 2009. Symbols in blue refer to observations in spring; red symbols are used for autumn campaigns. A significant gravity increase can be derived for this time period. Gravity values determined in autumn tend to be greater than values determined in spring. Gravity is compared with cumulative specific mass balance observations (greenish colors) for prominent glaciers within the Ötztal Alps (Austria) (Kuhn et al., 1999; Fischer and Markl, 2009; WGMS, 2011).

We do not take into account the ablation of rock glaciers as quantitative information is widely not available and exists only for very few places in the area of investigation, e.g. the Hochebenkar, $4 \mathrm{~km}$ south of Obergurgl (Schneider and Schneider, 2001). However, typical ice loss rates are estimated to be as small as $0.1 \mathrm{~m} \mathrm{yr}^{-1}$. The gravity effect of downwards mass flow between 1936 and 1997 is less than $0.5 \mathrm{~nm} \mathrm{~s}^{-2}$ at Obergurgl. Therefore, neglecting the rock glacier ablation is justified.

The accuracy of the glacier inventory products is improving with the methods employed. From a study by Würländer and Eder (1998) a vertical accuracy of $\pm 1.9 \mathrm{~m}$ can be inferred for the photogrammetric evaluations of 1969 and 1997. For the lidar-derived models the estimate of the vertical and horizontal accuracy is \pm 0.1 and \pm 0.3 m respectively (Abermann et al., 2010). Applying common error propagation laws, the errors of the elevation difference are $\pm 1.9 \mathrm{~m}$ for the period 1997-2006 and $\pm 2.7 \mathrm{~m}$ for the period 1969-1997.

Another important aspect is the methodology of glacier boundary delineation, which has been performed by interpreting relief-shaded DEMs according to the strongest roughness changes and surface elevation differences for the same location at different times (Abermann et al., 2010). Eighty (80) \% of ground-truthed values from geodetic 
measurements on test sites have shown an absolute horizontal deviation of below $4 \mathrm{~m}$ for glacier boundaries derived from lidar-acquired DEMs.

\section{1 Ötztal Alps}

Abermann et al. (2009) calculated volume changes of $-1.3 \mathrm{~km}^{3}$ between 1969 and 1997 and $-1 \mathrm{~km}^{3}$ between 1997 and 2006 by subtracting the corresponding DEMs from each other with a spatial resolution of $5 \mathrm{~m} \times 5 \mathrm{~m}$. The volume changes correspond to a mean thickness decrease of $-9.5 \mathrm{~m}$ and $-8.2 \mathrm{~m}$, respectively. The minimum altitude of ice cover has moved up to an elevation of $2060 \mathrm{~m}$ to $2120 \mathrm{~m}$, suggesting a positive gravity effect as the absolute gravity station in Obergurgl is located at lower altitude (about $1935 \mathrm{~m}$ ). However, the glacier retreat did not develop uniformly. Mass balance measurements on three glaciers in the surrounding area of Obergurgl (Hintereisferner, Kesselwandferner, Vernagtferner) (Fig. 3) demonstrate an ice mass gain between 1973 and 1985 (Kuhn et al., 1999; Fischer and Mark1, 2009; WGMS, 2011). This is important for modeling the Newtonian effect of glacier ablation.

\subsection{Stubai Alps}

Similar to the Ötztal Alps, the Stubai Alps' glaciers were investigated in 1969 and 1997 by analogue and digital photogrammetry and in 2006 by airborne laser scanning (Seiser, 2010). The total volume loss of all glaciers in the Stubai Alps is about $0.47 \mathrm{~km}^{3}$ in the period $1969-1997$ and $0.27 \mathrm{~km}^{3}$ in the period 1997-2006. The Übeltalferner is situated on the Italian side of the Stubai Alps and thus was not considered by Seiser (2010). Christoph Knoll (University of Innsbruck, personal communication, 2011) provided a DEM with $20 \mathrm{~m} \times 20 \mathrm{~m}$ resolution and digitized glacier boundaries for the year 1996. At this time, glacial masses covered nearly $8 \mathrm{~km}^{2}$ with a distance of approximately $15 \mathrm{~km}$ to Obergurgl. Roberto Dinale (Hydrographic Office Bozen, personal communication, 2011) made glacier reports available. Di Lullo et al. (2010) report a cumulative specific mass balance of $-7441 \mathrm{~mm}$ water equivalent since 2001/2002 for the year 2008/2009.

\section{Modeling}

The most accurate method for calculating the gravitational effects of ice loss is the polyhedron approach (e.g. Götze and Lahmeyer, 1988). However, the spatial resolution of the digital glacier models is rather high: For the Ötztal Alps, it is $5 \mathrm{~m}$ for the 1969 and 1997 inventories, and for 2006 the resolution is even better $(1 \mathrm{~m})$. Therefore, the polyhedron method would be extremely time consuming. The very small grid size and the generally large distances $(>1 \mathrm{~km}$, see Fig. 1) to the gravity station Obergurgl justify the application of a flattopped prism approach. The Newtonian effect of the vertical

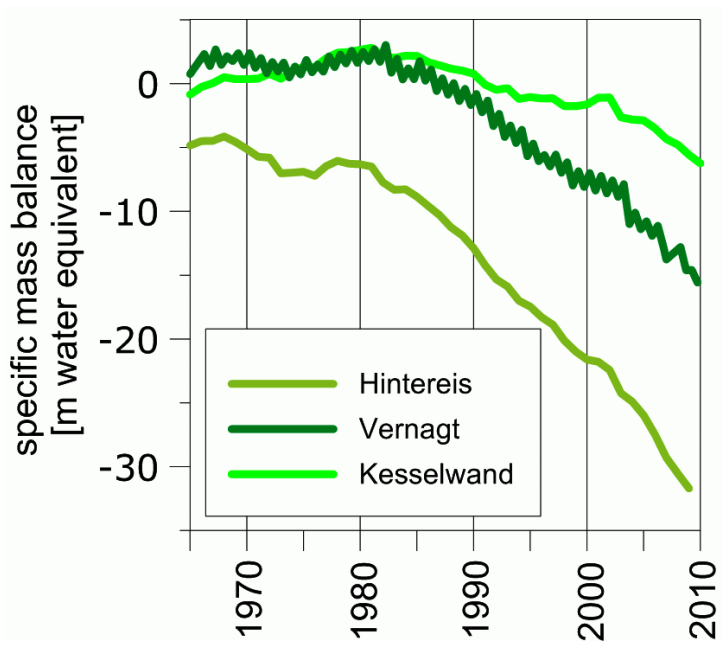

Fig. 3. Cumulative specific mass balance for three glaciers within the Ötztal Alps (Austria) (Kuhn et al., 1999; Fischer and Markl, 2009; WGMS, 2011). Glacier mass loss starts at about 1982.

prisms is then accurately calculated (e.g. Rösler, 1984) using an average ice density of $900 \mathrm{~kg} \mathrm{~m}^{-3}$ (e.g. Abermann et al., 2011). The curvature of the earth has to be taken into account. In the following section we describe roughly the model geometry. More details on the glacier modeling are provided by Arneitz (2012).

\section{1 Ötztal Alps}

Since the DEM grid points of different glacier inventories generally do not coincide, a specific data processing is required to determine the elevation changes. To simplify the interpolation process, the grid size of the younger inventory was assumed to be smaller than that of the older one. At the same step, grids were resampled to larger grid sizes in order to save computational efforts further. Again, this is well justified considering the distance of glaciers to Obergurgl. Due to limitations of the used resampling software, grid sizes could be enlarged only by steps of a factor of 2. Therefore the 1997 grid was resampled to $10 \mathrm{~m} \times 10 \mathrm{~m}$ and compared to the 2006 grid resampled to $8 \mathrm{~m} \times 8 \mathrm{~m}$. For the period 1969-1997, the 1969 grid was also resampled to $10 \mathrm{~m} \times 10 \mathrm{~m}$, but compared to the original $5 \mathrm{~m} \times 5 \mathrm{~m}$ grid of 1997 .

Figure 4 illustrates the computed elevation differences for the period 1997-2006, where mass loss is dominating. By closer inspection, also positive elevation changes occur. Positive values can be realistic in specific areas (Abermann et al., 2009), but especially at glacier edges glacial elevation can be distorted resulting in positive elevation changes. 


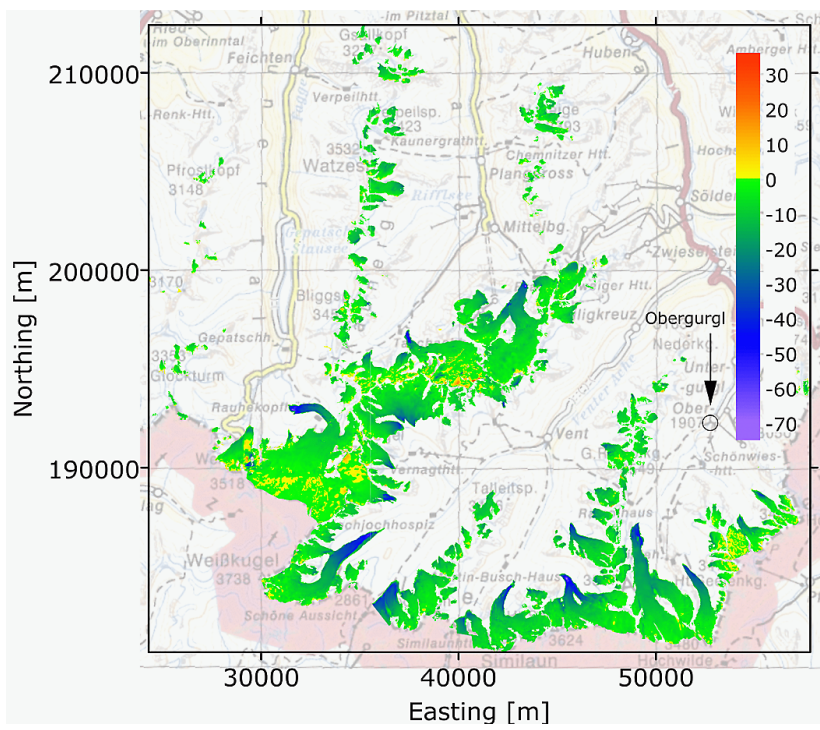

Fig. 4. Ice thickness variation (m) within the Ötztal Alps during the period between 1997 and 2006 derived from glacier inventories (Abermann et al., 2009). The small circle indicates the location of the gravity station in Obergurgl. Coordinates refer to the GaussKrüger coordinate system with central meridian $10^{\circ} 20^{\prime} \mathrm{E}$ (northing coordinate reduced by $5 \times 10^{6}$ ).

\subsection{Stubai Alps}

All glaciers of the Stubai Alps are located at horizontal distances larger than $10 \mathrm{~km}$ (see Fig. 1). Due to this fact, the computation process could be further simplified without significant loss of accuracy as proved by feasibility studies. Contrary to the Ötztal Alps, we no longer use the original DEMs of the inventories, but treat the glaciers depending on their size class instead. Within the Stubai Alps the glaciers of size class $4\left(1-5 \mathrm{~km}^{2}\right)$ contribute about $55 \%$ of the total volume loss. We derive mean elevation changes for each glacier from the overall mass loss determined by Seiser (2010). Then, the model was constructed by locating $25 \mathrm{~m}$ $\times 25 \mathrm{~m}$-sized prisms within the digitized glacier boundaries on top of topography. The average ice thickness change calculated for the period 1969-2006 was chosen as the prism height for all compartments of the specific glacier.

Size class $2\left(0.1-0.5 \mathrm{~km}^{2}\right)$ and $3\left(0.5-1 \mathrm{~km}^{2}\right)$ glaciers contribute about $27 \%$ and $15 \%$, respectively, to the total volume loss. For each glacier, the lost ice volume was approximated by only one rectangular prism with a basis area corresponding to the size class $(600 \mathrm{~m} \times 600 \mathrm{~m}$ for size class 2 and $1000 \mathrm{~m} \times 1000 \mathrm{~m}$ for size class 3 ). The individual prism height for each glacier representing the mean ice thickness change is derived from volume loss estimates by Seiser (2010). Glaciers of size class $1\left(0.01-0.1 \mathrm{~km}^{2}\right)$ are neglected due to their minimal contribution to the total ice volume loss.

The glacier area of the Übeltalferner from 1996 is extracted from a DEM with $20 \mathrm{~m} \times 20 \mathrm{~m}$ resolution $(\mathrm{C}$. Knoll, personal communication, 2011). Since no exact information about ablation is available the same mean ice thickness change is assumed as determined for the Ötztal Alps for the whole period 1969-2007.

Those glaciers south of the main divide that were not surveyed in the same years as the Austrian glacier inventories were treated similarly to the size class 2 and 3 glaciers of the Stubai Alps.

\subsection{Results}

Table 1 summarizes the gravity effect caused by ice loss during the two evaluation periods and clearly shows the dominant influence of the Ötztal glaciers. Only $10 \%$ of the gravity effect is due to the other glaciers. Based on the prism approach it is easy to investigate the dependency on the distance to the gravity station. For example, the circular area with $10 \mathrm{~km}$ around Obergurgl (Fig. 1) contributes by roughly $80 \%$. In fact, this proves that the simplification of the model geometry in the case of the Stubai Alps' glaciers and Übeltalferner is fully justified.

\section{Correction of the gravity time series}

Within the period between 1987 and 2009 several construction works were performed in Obergurgl and its surroundings. The expansion of a parking area and a building in the close vicinity of the gravity station as well as forest road widening and an avalanche gallery construction had measurable effects on gravity. Those man-made mass displacements were modeled primarily by modifying the DEM of the area around the observation site. The modified topography was approximated by polyhedrons with triangle-shaped surfaces that were generated by Delaunay triangulation (Renka, 1996). To exactly calculate the Newtonian effect of polyhedral bodies, the closed-form expression by Götze and Lahmeyer (1988) was applied. The gravity changes resulting from human interference do not exceed $-30 \mathrm{~nm} \mathrm{~s}^{-2}$ in total.

Calculating the gravity effect from digital glacier models at three dates $(1969,1997$, and 2006) gives the total estimated change in absolute gravity between these years. In order to compare the totals to the measured time series at Obergurgl we must decide how much of this melt occurred prior to 1985 . We therefore investigate 3 possibilities on how the ice melting rate changed over time. As shown in Figs. 2 and 3 , a mass gain was observed at the beginning of the period between 1973 and 1985 on three glaciers within the Ötztal Alps. The ice volume in 1985 was approximately the same as in 1973 (Kuhn et al. 1999; Abermann et al., 2009; Fischer and Markl, 2009; WGMS, 2011). Abermann et al. (2011) suggest adopting this behavior on average for all considered glaciers in the Eastern Alps. Three ice loss rate scenarios have been considered which are defined by different ice loss gradients (Fig. 5). Both scenario 2 and 3 take the mass gain 
Table 1. Computed gravity effects $(\delta g)$ due to ablation for all considered glacier areas for the periods 1969-1997, 1997-2006 and 1969-2006.

\begin{tabular}{lrrr}
\hline Glacier area & $\begin{array}{r}\delta g \\
\left(\mathrm{~nm} \mathrm{~s}^{-2}\right) \\
1969-1997\end{array}$ & $\begin{array}{r}\delta g \\
\left(\mathrm{~nm} \mathrm{~s}^{-2}\right)\end{array}$ & $\begin{array}{r}\delta g \\
\left(\mathrm{~nm} \mathrm{~s}^{-2}\right) \\
1997-2006\end{array}$ \\
\hline $\begin{array}{l}\text { Ötztal Alps } \\
\text { Stubai Alps }\end{array}$ & 122.3 & 81.3 & 203.6 \\
size class 2 & 2.0 & 1.0 & 2.9 \\
Stubai Alps & & & \\
size class 3 & 0.6 & 0.3 & 0.9 \\
$\begin{array}{l}\text { Stubai Alps } \\
\text { size class 4 }\end{array}$ & - & - & 5.3 \\
Übeltalferner & - & - & 3.4 \\
Missing glaciers & 4.0 & 5.0 & 9.1 \\
\hline Total & & & 225.2 \\
\hline
\end{tabular}

at the beginning of 1973 into account. Scenario 3 presents the maximum correction one can expect for the gravity time series.

Figure 6 (left panel, scenario 2) shows that the gravity trend decreases to $5.8 \mathrm{~nm} \mathrm{~s}^{-2} \mathrm{yr}^{-1}$ due to the applied correction and varies now from $4.8 \mathrm{~nm} \mathrm{~s}^{-2} \mathrm{yr}^{-1}$ (spring) to $6.0 \mathrm{~nm} \mathrm{~s}^{-2} \mathrm{yr}^{-1}$ (autumn). The overall trend is statistically significant only on the $1 \%$ level, while the trends for the seasons are insignificant. Scenario 3 presents a similar result (Fig. 6, right panel). In this case, the trend remaining after correction is statistically significant on an even lower significance level of $5 \%$. Here, the trend decreases to $4.8 \mathrm{~nm} \mathrm{~s}^{-2} \mathrm{yr}^{-1}$. Note that the man-made gravity effect has been corrected for in Fig. 6. This does not hold true for Fig. 2 showing the absolute gravimeter results without any correction. Correcting for man-made effects would increase the trend visible in Fig. 2 from 14.0 to $15.2 \mathrm{~nm} \mathrm{~s}^{-2} \mathrm{yr}^{-1}$. That means that the glacier ablation model explains $62 \%$ (scenario 2) and $68 \%$ (scenario 3), respectively, of the gravity increase.

\section{Discussion and conclusions}

The gravity time series achieved by absolute gravity observations in Obergurgl reveals a significant gravity increase between 1987 and 2009. Three-D modeling of the mass deficit above the measurement site caused by glacial ablation is the main approach for explaining this gravity increase. The analysis of DEMs for the Ötztal Alps proves to be an effective tool for evaluating the temporal elevation changes in glacial areas (Abermann et al., 2009). The gravity effect was determined by approximating the affected ice volume by very small-sized rectangular prisms $(5 \mathrm{~m} \times 5 \mathrm{~m}$ for 1969 1997 and $8 \mathrm{~m} \times 8 \mathrm{~m}$ for 1997-2006).

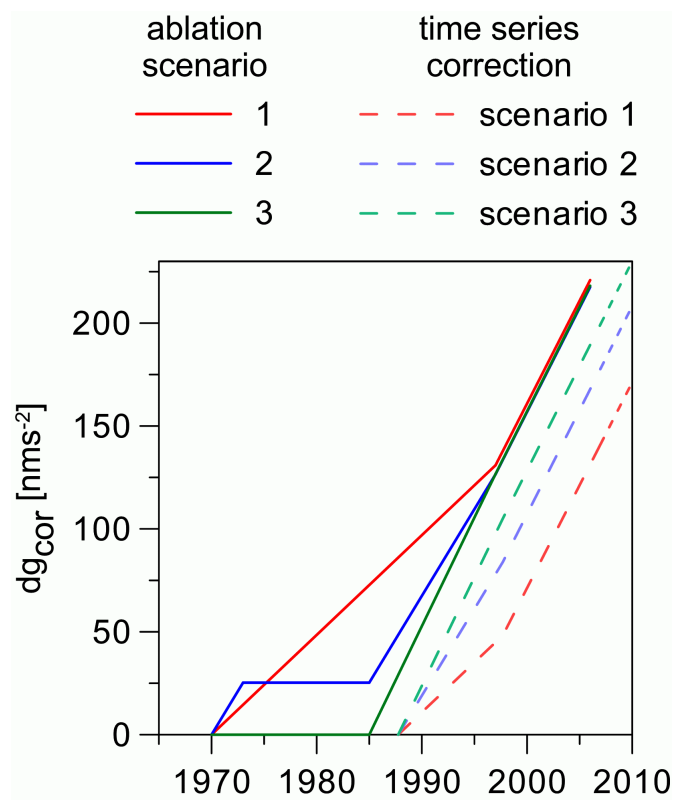

Fig. 5. Gravity effect of glacial ablation based on different ice loss rate scenarios. Solid lines indicate the gravity effect of the glacial ablation model during the entire inventory period, while the dashed lines show the corresponding correction applied on the observed gravity time series.

Before subtracting the Newtonian effect of glacial ablation, the gravity time series was corrected for small manmade effects $\left(-27 \mathrm{~nm} \mathrm{~s}^{-2}\right)$ due to construction work next to the station. Dates of construction work are quite accurately known except for the expansion of the parking area, which came about sometime around 1995. The ice mass loss rate was assumed to be constant during each inventory period, taking the ice thickness gain observed between 1973 and 1985 (Kuhn et al., 1999; Fischer and Markl, 2009; WGMS, 2011, Abermann et al., 2011) into account. Two scenarios were considered for the calculation of the ice loss rate by assuming no net ice loss between 1973 and 1985 (scenario 2) and between 1969 and 1985 (scenario 3), respectively. Beyond 2007 all correction values were extrapolated.

About $2 / 3$ of the gravity increase can be explained by the Newtonian effect of ice loss during the observation period between 1985 and 2009. The remaining trend visible in Fig. 6 is only weakly significant. Its origin is still open. Geodynamical processes like tectonic uplift or postglacial rebound would cause a gravity decrease and its correction would increase the remaining trend. Barletta et al. (2006) investigated the elastic response to ice mass loss in the Alps due to glacier shrinkage. At Obergurgl, a vertical uplift of 0.2 to $0.3 \mathrm{~mm} \mathrm{yr}^{-1}$ can be estimated. Based on this estimate, a gravity decrease of about -15 to $-20 \mathrm{~nm} \mathrm{~s}^{-2}$ is expected including local effects like those modeled by Mémin et al. (2009). However, the rebound effect cannot be detected by the corrected observations. Provided its estimate is true, it is masked 

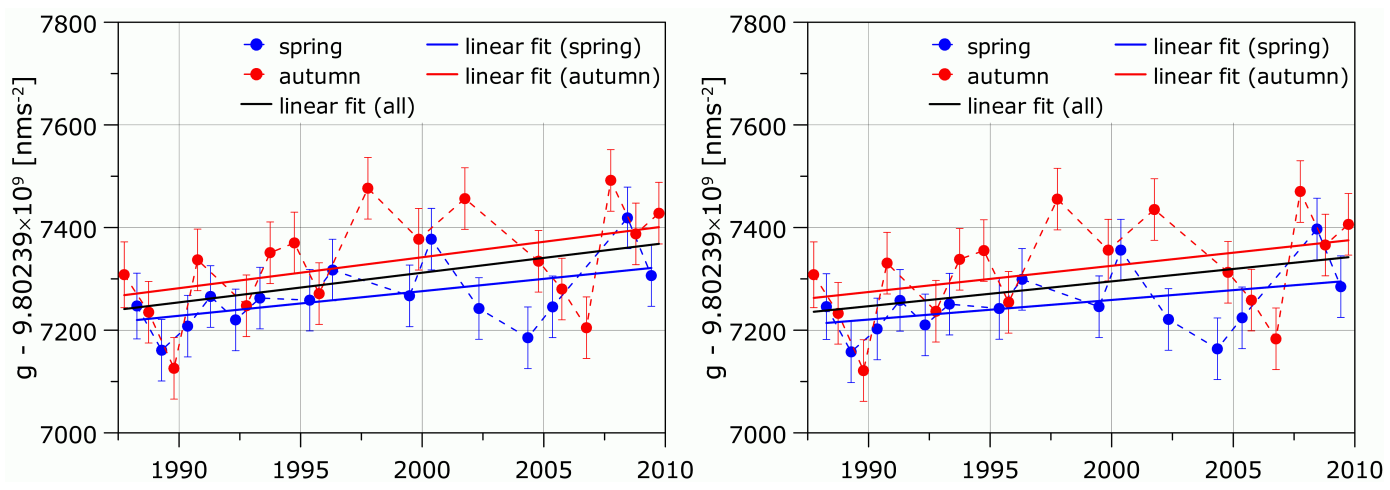

Fig. 6. Gravity variation at Obergurgl corrected for the effect of glacial ablation based on the scenario 2 (left) and scenario 3 (right). Scenario 3 represents the maximum possible gravity increase due to ice loss.

by still-unexplained processes like local hydrology, erosion, denudation etc. The same holds for isostatic or tectonic uplift processes as indicated by recent crustal movement observations (Höggerl, 2001; Haslinger et al., 2007). An appropriate evaluation requires a precise determination of potential elevation changes at the measuring point. Groundwater level variations could be another factor, and its rise would cause positive gravity changes. Unfortunately, both questions cannot be clarified as corresponding data sets are presently not available.

Erosion processes are another candidate for long-term gravity changes. Estimates of bed load transport are available only for some few rivers. For example, the sediment transport into the Gepatsch reservoir located in the Kauner valley $22 \mathrm{~km}$ west of Obergurgl consists of $12.000 \mathrm{~m}^{3}$ bed load and $46.000 \mathrm{~m}^{3}$ suspended load per year (Tschada and Hofer, 1990). Considering the catchment area of $55 \mathrm{~km}^{2}$ this corresponds to an average erosion rate of $1 \mathrm{~mm} \mathrm{yr}^{-1}$. However, it is impossible to derive reliable models for the calculation of gravitational effects from these numbers alone.

Glacial ablation explains about $2 / 3$ of the observed gravity variations. The trend remaining after corrections can be regarded as caused by a mixture of hydrological and geodynamical processes and instrumental uncertainties. Man-made mass displacements explain neither the erratic variations in the measurement series nor the gravity increase. Seasonal snow cover variations result in an average offset of $64 \mathrm{~nm} \mathrm{~s}^{-2}$ of the spring with respect to the autumn observation.

We highly recommend extending the gravity time series in future in order to investigate the on-going dynamical/tectonic processes. The instrumentation available today has much improved accuracy; thus the prolongation of the gravity time series will help to clarify open questions regarding geodynamical as well as seasonal effects. Of course, gravity measurements are not an appropriate method for investigating glacier shrinkage. Deriving the change in mass geometry from observing gravity at one location or even aerially is an illposed, problematic approach. Contrarily, the paper shows the extremely important role of glacier inventories in studying geodynamical processes in the Alps or in any other glaciercovered area by means of absolute gravimetry. Repeated glacier inventories with high spatial resolution are mandatory. Additional geodetic, hydrological and meteorological data would be essential in this context as well. It is expected that the instrumental upgrade from the JILAg-6 to FG-5 absolute gravimeter, which meanwhile has been implemented, will reduce the scatter of the observation results remarkably.

Acknowledgements. The authors thank the Central Hydrographic Office (Vienna) and the Commission of Geophysical Research of the Austrian Academy of Sciences. Suggestions and comments of two anonymous reviewers helped to improve the paper remarkably, which is gratefully acknowledged.

Edited by: G. Hilmar Gudmundsson

\section{References}

Abermann, J., Lambrecht, A., Fischer, A., and Kuhn, M.: Quantifying changes and trends in glacier area and volume in the Austrian Ötztal Alps (1969-1997-2006), The Cryosphere, 3, 205215, doi:10.5194/tc-3-205-2009, 2009.

Abermann, J., Fischer, A., Lambrecht, A., and Geist, T.: On the potential of very high-resolution repeat DEMs in glacial and periglacial environments, The Cryosphere, 4, 53-65, doi:10.5194/tc-4-53-2010, 2010.

Abermann, J., Kuhn, M., and Fischer, A.: A reconstruction of annual mass balances of Austria's glaciers from 1969 to 1998, Ann. Glaciol., 52, 127-134, 2011.

Arneitz, P.: Interpretation of temporal gravity variations in Obergurgl - effect of glacial ablation, Diploma thesis, University of Vienna, 75 pp., 2012.

Barletta, V. R., Ferrari, C., Diolaiuti, G., Carnielli, T., Sabadini, R., and Smiraglia, C.: Glacier shrinkage and modeled uplift of the Alps, Geophys. Res. Lett., 33, 14307, doi:10.1029/2006GL026490, 2006.

Di Lullo, A., Dinale, R., and Schrott, D.: Übeltalferner, Haushaltsjahr 2008/2009, Glacierreport, no. 02/2010, Sonderdruck zum 
Climareport Nr. 178, Hydrographisches Amt Bozen, Lawinenwarndienst - Wetterdienst, 2010.

Fischer, A. and Markl, G.: Mass balance measurements on Hintereisferner, Kesselwandferner and Jamtalferner 2003 to 2006: database and results, Z. Gletscherkunde Glazialgeol., 42, 47-83, 2009.

Götze, H. J. and Lahmeyer, B.: Application of three-dimensional interactive modeling in gravity and magnetics, Geophysics, 53, 1096-1108, 1988.

Haslinger, C., Krauss, S., and Stangl, G.: The Intra-Plate Velocities of GPS Permanent Stations of the Eastern Alps, Österr. Z. Vermessung Geoinform., 2, 66-72, 2007.

Höggerl, N.: Bestimmung von rezenten Höhenänderungen durch wiederholte geodätische Messungen, in: Die Zentralanstalt für Meteorologie und Geodynamik 1851-2001, 150 Jahre Meteorologie und Geophysik in Österreich, 630-644, edited by: Hammerl, C., Lenhardt, W. A., Steinacker, R., and Steinhauser, P., Leykam, Graz 2001, ISBN 3-7011-7437-7, 2001.

Jiang, Z., Francis, O., Vitushkin, L., Palinkas, V., Germak, A., Becker, M., D’Agostino, G., Amalvict, M., Bayer, R., BilkerKoivula, M., Desogus, S., Faller, J., Falk, R., Hinderer, J., Gagnon, C., Jakob, T., Kalish, E., Kostelecky, J., Chiungwu Lee, Liard, J., Lokshyn, Y., Luck, B., Mäkinen, J., Mizushima, S., Le Moigne, N., Origlia, C., Pujol, E.R., Richard, P., Robertsson, L., Ruess, D., Schmerge, D., Stus, Y., Svitlov, S., Thies, S., Ullrich, C., Van Camp, M., Vitushkin, A., Ji, W., and Wilmes, H.: Final report on the Seventh International Comparison of Absolute Gravimeters (ICAG 2005), Metrologia, 48, 246-260, 2011.

Kuhn, M., Dreiseitl, E., Hofinger, S., Markl, G., Span, N., and Kaser, G.: Measurements and models of the mass balance of Hintereisferner, Geogr. Ann. A, 81, 659-670, 1999.

Kuhn, M., Lambrecht, A., Abermann, J., Patzelt, G., and Gross, G.: Die Österreichischen Gletscher 1998 und 1969, Flächen- und Volumenänderungen, Verlag der Österreichischen Akademie der Wissenschaften, Wien, 125 pp., 2008.

Lambrecht, A. and Kuhn, M.: Glacier changes in the Austrian Alps during the last three decades, derived from the new Austrian glacier inventory, Ann. Glaciol., 46, 177-184, 2007.

Mémin, A., Rogister, Y., Hinderer, J., Llibes, M., Berthier, E., and Boy J.-P.: Ground deformation and gravity variations modelled from present-day ice thinning in the vicinity of glaciers, J. Geodynam., 48, 195-203, 2009.

Neumeyer, J. and Pflug, H.: ADMITT - a Program for Determination of the Atmospheric Pressure Admittance, Bulletin d'Informations Marées Terrestres, 127, 9851-9855, 1997.

Niebauer, T. M.: The Effective Measurement Height of Free-fall Absolute Gravimeters, Metrologia, 26, 115-118, 1989.

Patzelt, G.: The Austrian glacier inventory: status and first results, Riederalp Workshop 1978 - World Glacier Inventory, IAHSAISH Publ. no. 126, 181-183, 1980.

Renka, R. J.: ALGORITHM 751, TRIPACK: Constrained twodimensional Delaunay Triangulation Package, ACM, Trans. Math. Softw., 22, 1-8, 1996.

Rösler, R.: Theoretische Grundlagen der angewandten Gravimetrie und Magnetik, in: Angewandte Geophysik, Band 1, Gravimetrie und Magnetik, edited by: Militzer, H. and Weber, F., Springer Verlag, Akademie Verlag, 353 pp., 1984.

Ruess, D.: Schwerevariationen im Alpinen Raum, Proc. 6. Int. Alpengravimetrie-Kolloquium Leoben 1993, Österr. Beitr. Me- teorol. Geophysik, Heft 8, 113-126, 1993.

Ruess, D. and Gold, W.: The Austrian Gravity Base Net 1995 stabilized by Absolute Gravity Measurements and Connected to the European Network Adjustment, Österr. Z. Vermessung Geoinform., 3, 275-283, 1996.

Ruess, D. and Höggerl, N.: Bestimmung rezenter Höhen- und Schwereänderungen in Österreich, in: Pangeo Austria, edited by: Friedl, G., Genser, J., Handler, R., Neubauer, F., and Steyrer, H. P., Institut für Geologie und Paläontologie, Universität Salzburg, Salzburg, 151 pp., 2002.

Ruess, D. and Ullrich, C.: 20 years of International Comparisons of Absolute Gravimeters (ICAG) at the Bureau International des Poids et Mesures (BIPM) in Paris with Participation of BEV, Austrian Contributions to the XXV General Assembly of the International Union of Geodesy and Geophysics (IUGG), Österreichische Zeitschrift für Vermessung und Geoinformation, 99, 154-161, http://www.ovg.at/uploads/media/13_Ruess_ et_.pdf, 2011.

Schneider, B. and Schneider, H.: Zur 60jährigen Meßreihe der kurzfristigen Geschwindigkeitsschwankungen am Blockgletscher im Äußeren Hochebenkar, Ötztaler Alpen, Tirol, Z. Gletscherkunde Galzialgeol., 37, 1-33, 2001.

Schwiderski, E.: Ocean tides, Part I: Global ocean tidal equations, Part II: A hydrodynamical interpolation model, Mar. Geod., 3, 161-255, 1980.

Seiser, B.: Gletscherinventar 2006 der Stubaier Alpen, Diploma Thesis, University of Innsbruck, 71 pp., 2010.

Timmen, L.: Precise definition of the effective measurement height of free-fall absolute gravimeters, Metrologia, 40, 62-65, 2003.

Timmen L. and Wenzel H. G.: Worldwide synthetic gravity tide parameters available on internet, Bulletin d'Informations, Bureau Gravimétrique International, 75, 32-40, Toulouse, 1994.

Tschada, H. and Hofer, B., Total solids load from the catchment area of the Kaunertal hydroelectric power station: the results of 25 years of operation, IAHS Publication No. 194, 121-128, 1990.

Ullrich, C. and Ruess, D.: High precise gravity monitoring in Austria - examples and accuracy assessment, EGU General Assembly, Vienna, Austria, 2-7 April 2006, EGU06-A-02887, 2006.

Warburton, R. J. and Goodkind, J. M.: The influence of barometricpressure variations on gravity, Geophys. J. Roy. Astr. S., 48, $281-$ 292, 1977.

Wenzel, H. G.: Earth tide data processing package ETERNA 3.20, Bulletin d'Informations Marées Terrestres, 120, 9019-9022, 1994.

Wessel, P. and Smith, W. H. F.: Free software helps map and display data, EOS Trans. AGU, 72, 441-446, 1991.

WGMS (2011): Glacier Mass Balance Bulletin No. 11 (20082009), edited by: Zemp, M., Nussbaumer, S. U., Gärtner-Roer, I., Hoelzle, M., Paul, F., and Haeberli, W., ICSU (WDS) / IUGG (IACS) / UNEP / UNESCO / WMO, World Glacier Monitoring Service, Zurich, Switzerland, 102 pp., 2011.

Würländer, R. and Eder, K.: Leistungsfähigkeit aktueller photogrammetrischer Auswertemethoden zum Aufbau eines digitalen Gletscherkatasters, Z. Gletscherkunde Glazialgeol., 34, 167-185, 1998.

Zumberge, M. A.: A Portable Apparatus for Absolute Measurements of the Earth's Gravity, Ph.D. Thesis, University of Colorado, 1981. 